\title{
The Role of Village Owned Enterprises in Increasing the Rural Economy
}

\author{
Gde Deny Larasdiputra ${ }^{1, a, \#}$, Putu Budi Anggiriawan ${ }^{1, \mathrm{~b}}$, Putu Gede Wisnu Permana Kawisana ${ }^{1, \mathrm{c}}$ \\ I Gst. B. Ngr. P. Putra ${ }^{1, d}$ \\ ${ }^{1}$ Faculty of Economics and Business Warmadewa University, Denpasar, bali, Indonesia

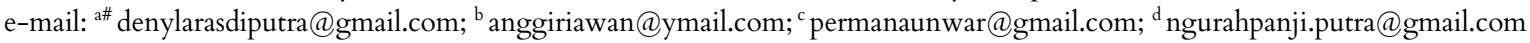 \\ \#Corresponding Author \\ Whatsapp Number $\{+62-81944822418\}$
}

\section{ARTICLE HISTORY}

Received: 23 March 2019

Revised: 25 April 2019

Accepted: 20 June 2019

Copyright $\odot 2019$ Authors \& Published by IIES Independent. This is an open-access article distributed under the terms of the CC-BY-SA License.

\section{ABSTRACT}

This research was conducted with qualitative methods that adopted Community Based Research (CBR), by taking the location of research in Pejarakan Village, Buleleng Regency which is one of the villages with good management of Village-Owned Enterprises and has many synergistic entrepreneurial communities. The results of this study are that the use of Mandara Gerbangsadu funds from the Government has been allocated well for the economic development of the village, therefore the VillageOwned Enterprise collaborates with the entrepreneurial community to develop the potential of the community with the aim of improving the welfare of the community and proving that the Village-Owned Enterprise as a place for village entrepreneurship able to improve the economy of the community through the development of a productive economy.

Keywords: Village Owned Enterprises, entrepreneurial community, and village economy

How to Cite: Larasdiputra, G., D., Anggiriawan, P., B., Kawisana, P., G., W., P., T., \& Putra, I., G., B., N., P (2019). The Role of Village Owned Enterprises in Increasing the Rural Economy. International Journal of Advances in Social and Economics, 1 (2), 60-66.

\section{Introduction}

Village-Owned-Enterprises (BUMDesa) are built based on Law Number 6 of 2014 concerningVillages referred to as villages established by Village-Owned Enterprises, this supports approval in article 213 (paragraphs 1-3) of Law No. 32 of 2004 concerning Local government. Village community initiatives based on cooperative, participatory, and emancipatory principles whose management must be carried out professionally and independently. BUMDesa is a form of village institution that has economic or business activities to obtain useful benefits for the village community. Villages collecting BUMDesa are not solely for profit, but also benefit social and other non-economic benefits. The economic benefits obtained from BUMDesa's business activities are certainly a financial gain or benefit, the increase in Village Original Income, the opening of new employment opportunities for rural communities and increasingly dynamic village economic activities.
Other social and non-economic benefits of BUMDesa are expected to be able to strengthen the sense of togetherness among villagers, strengthen mutual cooperation, foster pride of citizens towards their villages, accommodate entrepreneurial communities in the village and also encourage the growth of initiatives and movements with citizens to develop villages independently. One of the benefits gained from establishing BUMDesa is accommodating the existing entrepreneurial communities in the village as the main attraction for young entrepreneurs who are committed to developing the village economy and care about their village. In Bali, especially in several villages in Buleleng Regency there are many BUMDesa that have been operating, even have a significant impact on the development of entrepreneurship in the village and become a magnet for other entrepreneurial communities to develop various types of businesses in the village in the form of product or service products. 
This was a positive trigger for other community members to compete in forming BUMDesa based on the needs and potential of the local village community.

The manifestation of the government's role in improving the village economy in Bali with the program of the Mandara Integrated Village Development Movement (Gerbangsadu mandara) from the Bali Provincial Government has also encouraged the growing interest in entrepreneurship from rural communities. One example of the Gerbangsadu beneficiary village is Babakan Village, Gianyar Regency. Village-Owned Enterprises (BUMDesa) have succeeded in developing the creativity of their communities with the creation of locally owned products, such as keben, bamboo and clay and other handicrafts. Likewise in villages in Buleleng Regency that have a lot of potential in developing BUMDesa as an entrepreneurial forum in the village. Like the one in Pejarakan Village, Buleleng Regency, BUMDesa in the form of cooperatives and mini markets accommodates entrepreneurs in the field of handicrafts and culinary such as ingke crafts, as well as traditional ceremonial equipment in Bali. Another example in Buleleng Regency Penyabangan Village is BUMDesa in the field of shops and photocopies, this business is used by entrepreneurs in the village to develop their businesses by utilizing village-owned shops.

From several examples of BUMDesa that synergize with entrepreneurs in the village, it can be seen that the contribution of business in the village to improving the economy of rural communities is very effective because the Village in this case through BUMDesa is able to accommodate the creativity of the community through entrepreneurship, and positive benefits for rural entrepreneurs less valued and less well known, with BUMDesa this can be more explored and known by the wider public. This research was conducted in one of the BUMDesa in Pejarakan Village, Gerokgak District, Buleleng Regency. BUMDesa manages the Productive Economic Business from the Sadu Mandara Gate fund of Rp 800.000.000,- to improve the economy of small communities and open new workspaces and is expected to be able to alleviate poverty and prosper the rural community. The Sadu Mandara Gate is a program given by the Governor of Bali in 2012 to the Villages in Bali whose figures for Poor Households (RTS) are more than 35\% of the number of households in the village.

\section{Literature Review}

\section{Entrepreneurship Theory}

Drucker (1985) interpreted entrepreneurship as the spirit, ability, attitudes and behavior of individuals in handling business (activities) that lead to efforts to find, create, implement work methods, technology, and new products by increasing efficiency in order to provide better services and or get bigger profits. Drucker (1985) also defines entrepreneurship as a process of creating something new (creation) and/or making something different (innovation), whose purpose is the achievement of individual welfare and added value to society.

As time went on, entrepreneurship grew, so various kinds of theories about entrepreneurship were born, I will try to explain various theories of entrepreneurship, including the following (Nurokhman, 2012; Sumartono, 2019).

Neoclassical Theory, refers to a company as a technological term, where management (individuals) only knows the costs and revenues of the company and merely performs mathematical calculations to determine the optimal value of the decision variable.

Kirzerian Entrepreneur, highlights about human performance, tenacity, seriousness, importance, for self (independent), in trying, so that the progress of a business depends on the efforts and tenacity of the entrepreneur.

Behavior theory, states how an entrepreneur must have the skills in organizing a business, managing finance and related matters, building a network, and marketing products, needed by a person who is sociable and good at getting along to advance a business.

\section{Village Entrepreneurship Community}

Village Entrepreneurship is intended to invite and foster the spirit of youth and rural communities to develop potential in their area (local potential) with entrepreneurship. By definition it is stated that the entrepreneurial community is a group of people/ individuals or groups who share the same commitment with the aim of opening a business to improve economic prosperity. The entrepreneurial community in the village is very significant needed by the village in order to increase the village's original income by developing and exploring village potential from various types of businesses.

The entrepreneurial community in the village has seen more steps when synergizing with the village and helping the village in determining the type of business established in the village. This community is one of the economic institutions in the village, while the village 
apparatus or village government highly appreciates the entrepreneurial community formed in his village in the form of the establishment of BUMDesa, an exhibition of village business results or other economic improvement strategies.

\section{Village-Owned-Enterprises (BUMDesa)}

Village-Owned-Enterprises, abbreviated as BUMDesa, are village business institutions managed by the community and village government in an effort to strengthen the village economy and are formed based on community needs and village potential (Hartowiryono and Suharyanto, 2014). BUMDesa is a form of village institution that has activities to run an economic or business enterprise to obtain useful benefits for the welfare of rural communities.

According to Village Minister Regulation No. 4 of 2015 Article 1 states that business entities whose entire or part of their capital is owned by the Village through direct participation derived from village assets are separated to manage assets, services and other businesses for the greatest welfare of the village community. BUMDesa is basically a form of consolidation or strengthening of village economic institutions and is an instrument for utilizing the local economy with various types of potential, which aims to improve the economic well-being of rural communities through the development of their economic enterprises, and contribute to village income that enables villages able to carry out development and improve community welfare optimally (Ferdianto, 2016).

\section{Method}

\section{Research Design}

Research uses a qualitative approach. The choice of a qualitative research model is highly dependent on the point of view used by the researcher and research objectives (Creswell, 2007). Some qualitative research can be done in the perspective of Symbolic Interactionism, semiotics, existential phenomenology, constructivism and critical (Searcy \& Mentzer, 2003). Qualitative research can use several methods to answer research questions. As a result ideally, conducting qualitative research requires "strong commitment to study a problem" and "demands time and resources" (Sukoharsono, 2006: 232).

In this study there are phenomena that arise in the community that are related to the emergence of village entrepreneurial communities that are driving the economy of rural communities, so that this community is utilized by synergizing with BUMDesa to realize village economic prosperity and increase village income. This study describes the meaning of a number of individuals' experience of a phenomenon. Phenomenology as a method has four characteristics, namely descriptive, reduction, essence and intentionality. As stated by O'Donoghue \& Punch (2003) "the phenomenological method, which consists of four key qualities (i.e. description, reduction, essences and intentionality) is common to all types of penomenology". The purpose of using this phenomenological qualitative approach is to understand the essence of one's experience by grouping existing issues and giving meaning to the issue according to the person's view.

\section{Research Focus}

BUMDesa was formed to strengthen the village economy so as to increase the village's original income. The problem that has happened so far is that many BUMDesa do not work and even go bankrupt, so it needs to be studied that the potential of the village community must be empowered to be able to support the village economy. This study sought to understand the objectives of the establishment of BUMDesa, the synergy of entrepreneurship with BUMDesa and the use of village funds (Gerbangsadu Mandara funds) for the purpose of improving the village economy, so as to realize the welfare of the community and village independence in Pejarakan Village, Buleleng Regency.

\section{Research Location}

The location of this study is in BUMDesa Pejarakan Village, Buleleng-Bali Regency as one of the BUMDesa which is classified as advanced and has good synergy with village entrepreneurs, as well as coordinated and accountable Gerbangsadu Mandara Fund management. For this reason, with BUMDesa going forward, whether the contribution to the village's original income has been balanced and does not create new problems in the community by not creating a business model that is hegemony by certain groups at the village level.

\section{Data Sources}

The main data sources in this qualitative research are words and actions (Silverman, 2007 in Susilowati, 2013). Therefore the main instrument in this study is that researchers directly conduct interviews which are expected to be able to analyze qualitative data obtained from informants. The data sources in this study were 
the managers of BUMDesa, the Village Head, the Village Consultative Body (BPD), and local community leaders.

\section{Data Collection Procedure}

The right data collection procedure will result in the collection of data as expected. This study uses two data collection techniques, namely (1) in-depth interviews and (2) documentation studies. This interview technique is an unstandarded interview, which means that the interview guide used is not absolute and loose (Susilowati, 2013). The process of collecting data in phenomenology is the stage of understanding something from an informant's point of view (understanding the world of the subject points of view, to unfold meaning of people experiences) (Groenewald, 2004: 13).

\section{Data Analysis Method}

This study uses the Community Based Research (CBR) approach, which is carried out qualitatively. Community Based Research is research carried out on a commitment from the community to provide strength, resources, and also involvement in the research process in order to produce research products that are beneficial to them, as well as researchers involved in the research process. Research initiatives can also come from scientists or researchers after seeing the problems and potential that exist in society, to provide solutions to the instrumentative technical formulations to solve problems faced by society, whether they are aware of it or not, so that they are carried away in the flow of change and progress (Banks, 2012).

Community Based Research (CBR) is not a method, nor an approach that will determine various data collection and analysis techniques, but, a research model that targets social communities as an active part of the research process, in order to improve the effectiveness of data collection and analysis processes. to produce a recommendation that is truly beneficial for improving the quality of their social life. While the research model itself is closer to the action research model (Hine, 2013). Action reviews are usually carried out collaboratively between researchers and their partners from social groups who are used as target groups in research. Thus, the basis of CBR research is qualitative, because it will always correspond between design and social needs, except that the academic process in the CBR does not seek meaning from phenomena, nor does it make interpretations of the meaning of phenomena, but rather formulates the design needed by society, based on the results of their own trials in real life (Rosyada, 2016).

\section{Results and Discussion}

\section{Utilization of Funds for the Establishment and Management of BUMDesa}

Various types of entrepreneurial communities in Pejarakan Village were optimized to synergize with BUMDesa with the aim of increasing village income. All types of businesses are developed and managed under BUMDesa so that Pejarakan Village is one of the villages that has BUMDesa which is highly developed in Buleleng Regency. Income from BUMDesa is very helpful for villages in terms of village operations and village government. In addition, in terms of management of BUMDesa, it can be said to be very professional and can be seen from the use of funds reported in a transparent and accountable manner. The management of BUMDesa in collaboration with entrepreneurial groups in the village is very effective seen and can be seen from various types of businesses that have been developed with regard to the potential of the village and its community, so that it has a positive impact on community economic development and human development in Pejarakan Village. The development of BUMDesa and the increasing role of entrepreneurship in the village as one of the support for government programs related to populist economy starting from the village. This was supported by the opinion of Pejarakan Village Chief I Made Astawa, following his statement:

"BUMDesa is a pillar of economic activity in the village that functions as a social and commercial institution. In carrying out its business the principle of efficiency and effectiveness must always be emphasized. Thus, the existence of BUMDesa is able to encourage the dynamics of economic life in the countryside and as a stimulus for entrepreneurs in the village in developing their businesses so that populist economic programs can be started from the village "

\section{Establishment of BUMDesa to Facilitate Entrepreneurs in the Village}

In accordance with the mandate of Article 213 of Law Number 32 Year 2004 concerning Regional Government, villages can establish village-owned enterprises (BUMDesa) to accommodate the economic activities of village communities. BUMDesa is thus an umbrella for all economic activities in the village. This means that BUMDesa can accommodate all village ec- 
onomic activities, without having to make other economic business fields. As stated by one of the BUMDesa managers in Pejarakan Village (I Putu Adi Suweca) as follows:

"BUMDesa Pejarakan Village states that this institution is a legal entity. It should be formed according to the potential of the village community. Through various business units, various basic needs of the villagers are expected to be accommodated and fulfilled. Furthermore, the selection of types/business units was submitted to the BUMDesa Management to inventory various needs and potential they had. The determination of the business units held has been discussed in the Musdes forum (the highest authority on BUMDesa) because each business unit that is formed contains risks ".

The statement states that the establishment of BUMDesa is based on Village Regulations and has binding legal force, so that villagers who want to market their handicraft products or plantation/ livestock products and other household creations can utilize the BUMDesa in Pejarakan Village, because BUMDesa is a shopping business and cooperatives so as to be able to accommodate all the work of the local community as a tremendous potential in sustaining increased village income. So far the existence of BUMDesa in Pejarakan Village has become one of the biggest contributors to the village's original income. This is evidenced by the performance of BUMDesa which is seen from its service, profit and sustainability of its business. The following is delivered by one of the village community leaders and at the same time as an entrepreneur in Pejarakan Village (I Wayan Karmita):

"BUMDesa in Pejarakan Village is carried out professionally and flexibly (free in developing all types of businesses). This can increase the productivity of the village community and the development of real business in BUMDesa can absorb a larger workforce and increase income. In addition to income, real efforts can also trigger the growth of other informal sectors and can encourage the creativity of the entrepreneurial spirit of the community in working "

BUMDesa is committed to accommodating the entrepreneurial community in the village with a very noble goal to facilitate product marketing and to introduce and market the potential of rural communities to the public. Businesses that until now have collaborated with BUMDesa in a shop business unit are young entrepreneurs who have high creativity such as woven crafts, accessories (bags, shoes, sandals), and crafts of religious ceremonies.
Many types of entrepreneurial communities have taken advantage of the existence of BUMDesa in Pejarakan Village. Some of them use BUMDesa as a marketing media for their industrial products, some also make BUMDesa as a partner in developing their business (capital) and other utilization models. The statement was given by a member of the BUMDesa Supervisor and community leader of Pejarakan Village (Made Parwata):

"BUMDesa Pejarakan Village is in the form of shops and cooperatives that have been committed and collaborated with entrepreneurs in the village in terms of product marketing and provide as much opportunities as possible for businesses to further enhance their creativity and work to develop. Businesses that have collaborated with BUMDesa are the craftsmen community of Balinese traditional ceremonies, and home-based businesses in the form of dry food and livestock businesses which are the business of the majority of the people of Pejarakan Village, but over time, Pejarakan Village plans to expand its business and embrace entrepreneurial groups in the tourism sector because of the tourism potential that were already possessed"

From these statements, it can be concluded that the purpose of the establishment of BUMDesa in Pejarakan Village is in accordance with the mandate contained in Law No. 6 of 2014 concerning Villages, which accommodates existing businesses in the village by paying attention to the potential of village communities. Thus, this can be interpreted that BUMDesa has complied with all government regulations and legislation and this can be assumed as an indication that BUMDesa's performance is in the best condition and has no problem in terms of management or financial reporting. Because, compliance with regulations becomes a reference in the management of BUMDesa to maintain the sustainability and performance of BUMDesa to remain optimal. The main thing contained in the results of the interview is that all types of businesses and village business actors can be accommodated in BUMDesa so that the village economic welfare goals can be achieved and the ability of the village and BUMDesa to create jobs for the community can be realized.

\section{BUMDesa As a Source of Strengthening Economy in the Village}

BUMDesa as a business entity, all or part of its capital is owned by the village through direct participation originating from village wealth, therefore, the development of BUMDesa is a form of strengthening 
of village economic institutions and a tool for utilizing local economies with various types of potential in the village, more than that BUMDesa is the backbone of the village government economy to achieve an increase in the welfare of its citizens. This is supported by a statement from the Chief of Pejarakan Village (I Made Astawa):

"The benefits of real efforts formed by BUMDesa are in accordance with the potential of the village, so that they can maximize excellence and benefits that will affect the surrounding community so that it can be used as a source of income for the people who manage BUMDesa businesses"

BUMDesa was built on the initiative of the village community, based on cooperative, participatory and emancipatory principles whose management must be carried out professionally and independently. As a village business, the establishment of BUMDesa is intended to encourage or accommodate all activities to increase community income, both those that develop according to local customs / culture and economic activities through government programs and regional government. Various things can be taken in the strategy of empowering the community's economic business through BUMDesa, such as creating a conducive business climate for the development of micro enterprises in the village and creating a guarantee system to support the productive economic activities of micro-enterprises.

Another thing that has become a noble goal in the establishment of BUMDesa is to encourage the development of informal micro-enterprises to absorb labor for people in villages who are free from the influence of other negative factors such as moneylenders or other illegal savings and loan systems and activities that do not provide positive benefits for the village community. So that the ideals of village development aimed at improving the welfare of the village community and the quality of human life and poverty reduction through the provision of basic needs, the construction of facilities and infrastructure, the development of local economic potential, and sustainable use of natural and environmental resources can be achieved. For this reason, an approach must be taken, namely "Village building" which is integrated in Village Development planning through strengthening the people's economy that is realized in the establishment of BUMDesa (Anwar, 2016).

\section{Conclusion}

The establishment of BUMDesa in Pejarakan Village greatly provides a great opportunity for village entrepreneurs to synergize with each other in terms of product marketing, dissemination of product information or open employment opportunities for the community. BUMDesa accommodates all types of entrepreneurship that develop in Pejarakan Village such as agriculture, animal husbandry, handicrafts, food and beverage businesses and other businesses that are the potential of Pejarakan Village community. Village entrepreneurs feel helped in all forms of business establishment, regulation or legality of their business by collaborating with BUMDesa. The establishment of BUMDesa and the professionalism of its management in Pejarakan Village can directly affect the economy of the village community so that it does not depend on assistance from the government, this supports the village's goal of becoming an independent village. The role of village entrepreneurship and collaboration between BUMDesa and business actors is a manifestation of empowering the village economy through rural economic activity units that have a significant influence on improving the economy of rural communities.

\section{Recommendations}

Recommendations or suggestions that can be given based on the results of the study are that all villages are expected to be able to provide a great opportunity for businesses in the village to interact with the village government in forming BUMDesa. In addition, BUMDesa must be able to accommodate entrepreneurs in the village to develop the potential of their communities and not create any form of social jealousy. If reviewed in terms of legality, it can be suggested that the establishment of BUMDesa be legally covered by Village Regulations so that rural business actors can freely creativity in developing their business or the type of product but not out of the applicable regulations.

\section{References}

Anwar, Muhamad Saeful. (2016). Membangun Ekonomi Pedesaan Melalui Strategi Konvensional. FISP, Universitas Jendral Achmad Yani.

Atmadja, A. T., \& Saputra, K. A. K. (2018). Determinant Factors Influencing the Accountability of Village Financial Management. Academy of Strategic Management Journal. 
Atmadja, A. T., Saputra, K. A. K., \& Koswara, M. K. (2018). The Influence Of Village Conflict, Village Apparatus Ability, Village Facilitator Competency And Commitment Of Local Government On The Success Of Budget Management. Academy of Accounting and Financial Studies Journal, 22(1), 1-11.

Banks, Sarah. (2012). Community Based Participatory Research A Guide to Ethical Principles and Practice, Center for Social Justice and Community Action, Durham University, UK. 2012, p. 6

Creswell, J. W. (2007). Qualitatif Inquiry and Research Design. Sage Publications, Inc: California.

Dewi, P. E. D. M., Saputra, K. A. K., \& Prayudi, M. A. (2017). Hubungan Kualitas Pengelolaan Aset Desa dan Pendapatan Asli Desa (Studi pada Desa-desa di Kabupaten Buleleng-Bali). Proceeding SENARI, 5, 253-260.

Drucker, P.F. (1985) "The Practice of Entrepreneurship", Innovation and Entrepreneurship Practice and Principles, Harper \& Row, New York, pp. 141-188

Drucker, P.F. (1985) "Entrepreneurial Strategies", Innovation and Entrepreneurship Practice and Principles, Harper \& Row, New York, pp. 207-243

Ferdianto, Benny. (2016). Eksistensi Badan Usaha Milik Desa terhadap Peningkatan Pendapatan Asli Desa di Tiyuh Candra Kencana Kecamatan Tulang Bawang Tengah Kabupaten Tulang Bawang Barat. Skripsi. Universitas Lampung.

Groenewald, Thomas. (2004). A Phenomenological Research Design Illustrated. International Journal of Qualitative Methods Vol. 3 (1) April, 2004.

Hartowiryono dan Suharyanto. (2014). Penyusunan Kelayakan Usaha dan Pengembangan Usaha BUMDesa. Australian Community Development and Civil Society Strengthening Scheme (ACCESS) Tahap II.

Hine, Gregory S. C. (2013). The importance of action research in teacher education programs, dal am Design, develop, evaluate: The core of the learninenvironment. Proceedings of the 22nd Annual Teaching Learning Forum, 7-8 February 2013. Perth: Murdoch University.

Nurokhman, Habib Amin. (2012). Kewiraushaan. http://www.kompasiana.com. Diakses tanggal 26 September 2016

O’Donoghue, Tom and Keith Punch. (2003) Qualitative Educational Research In Action. Doing and reflecting London: Routledge Falmer Pub.hlm.44
Peraturan Pemerintah Nomor 43 Tahun 2014 tentang Desa.

Peraturan Menteri Desa, Pembangunan Daerah Tertinggal, Dan Transmigrasi Republik Indonesia Nomor 4 Tahun 2015 Tentang Pendirian, Pengurusan Dan Pengelolaan, Dan Pembubaran Badan Usaha Milik Desa.

Rosyada, Dede. (2016). Community Based Research (CBR) Salah Satu Model Penelitian Akademik. http://www.uinjkt.ac.id/id/community-basedresearch-cbr-salah-satu-model-penelitianakademik/ Accsess on 4 October 2016.

Saputra, K.A.K dan I. P. Julianto. (2016). Pembentukan Bumdesa Dan Komunitas Wirausaha Untuk Meningkatkan Pembangunan Ekonomi di Desa. Prosiding Seminar Nasional TEAM 2016.

Saputra, K. A. K., Anggiriawan, P. B., \& Sutapa, I. N. (2018). Akuntabilitas Pengelolaan Keuangan Desa Dalam Perspektif Budaya Tri Hita Karana. Jurnal Riset Akuntansi Dan Bisnis Airlangga, 3(1).

Searcy, D.L. and J.T. Mentzer. (2003). "A Framework for Conducting and Evaluating Research", Journal of Accounting Literature, 22, pp. 130- 167.

Sugiyono. (2009). Metode Penelitian Bisnis. Alfabeta, Bandung.

Sukoharsono, Eko Ganis. 2006. Alternatif Riset Kualitatif Sains Akuntansi: Biografi, Phenomenologi, Grounded Theory, Ethnografi Kritis, dan Studi Kasus. Analisis Makro dan Mikro, BPFE Universitas Brawijaya, Malang.

Sumartono, E., Yuliarti, E., \& Nengsih, D. S. (2019). Perception of Millennial Generation of Farmer Children on Employment in Agricultural Sectors (Case Study of Farmer Children in Village Padang Cekur, Talo District, Seluma District). International Journal of Advances in Social and Economics, 1(1), 2227.

Susilowati, Nurdian. (2013). Sikap Mahasiswa Terhadap Undang-Undang Akuntan Publik Pada Optimisme Dan Perencanaan Karir. Simposium Nasional Akuntansi XV.

Undang-Undang Nomor 23 Tahun 2004 tentang Pemerintah Daerah.

Undang-Undang Nomor 6 Tahun 2014 tentang Desa. 